\title{
Factors Influencing Women Entrepreneurs'Business Success in Somalia
}

\author{
Nimco Salah Guled (Corresponding author) \\ Graduate Student \\ Business Administration, Istanbul Aydin University, Turkey \\ Tel: 00905419512127, E-mail: nimoguled066@gmail.com \\ Burcin Kaplan \\ Assistant professor \\ Business Administration, Istanbul Aydin University, Turkey \\ Tel:00905323502873, E-mail: burcinkaplan@aydin.edu.tr
}

Received: December 20, 2017 Accepted: December 31, 2017 Published: February 20, 2018

doi:10.5296/rbm.v5i1.12341ＵRL: http://dx.doi.org/10.5296/rbm.v5i1.12341

\begin{abstract}
Globalization has dramatically changed the role of opposite genders in world business. Today women entrepreneurship is increasing significantly in all over the world. However, it is widely recognized that women entrepreneurship is not only important for economic growth but also vital to improve the living standard of societies. Despite of these facts, women's contribution in entrepreneurship is lower than men's in nearly all societies and various factors are effecting on their success. Thus, the purpose of this study is to elaborate the factors such as financial capital, fund support, socio economic influence, market \& network and government influence on the success of women entrepreneurs business in Somalia. Nonetheless to identify these factors impact, researcher chose quantitative research base study with primary data. Women entrepreneurs from SME (Small \& Medium Enterprises) in Somalia were selected as target sample and total of 100 sample size was chosen. Questionnaire was used as instrumentation of data collection. Additionally, convenience sampling was carried out to select target respondents for collect the data. Moreover, Bivariate and reliability analysis was carried out with the help of SPSS (statistical Package for social sciences) for data analysis. Main findings reveals that government support, market\& network, fund support and market $\&$ network factors are significantly impact on women entrepreneur in Somalia. Moreover no significant impact was found for the socio economic factors on women entrepreneur business success.
\end{abstract}

Keywords: Women Entrepreneurs Success, SMEs, Somalia

\section{Introduction}

Economic growth of any country significantly linked with Entrepreneurs. These are the persons with problem solving skills, necessary capital and ability to generate new ideas in marketing to promote their products and services and also make the right decisions to ensure that the ideas are profit oriented. However, the achievements and success in business as well as profit are the motivated factors of entrepreneurs Rashid et al., (2015). Successful entrepreneur is always leading their business towards continuous improvement through creativity and innovation in producing new and existing products or services. "Women 
entrepreneurs are women that can play a noteworthy part to increase the social and economic development, especially in the small \& medium businesses" (Ahmed, 2011).

Women owned SMEs in Somalia are greatly increasing in the economies of nearly in all regions of the country. The unknown potentials of women entrepreneurial have progressively been altering with the rising sensitivity to the role and economic status in the society. Women were seemed to be dominated to helping men in financial providing, leadership as well as in social needs in Somalia in an autocratic manner but after that they start various businesses in diverse sectors. Particularly, they are considered as the backbone of country economy as well as for the family and household. Over the last two decades Somali married and unmarried women became major economic providers to the families.

Despite of increasing number of women entrepreneur in Somalia, they are facing last of hurdles to achieve success such as lack of government support, lack of fund and family support Osman and Salleh, (2007) and lack approach towards new technologies to promote their products ILO, (2003). Additionally, in recent years women-owned businesses are one of the fastest growing entrepreneurial populations in the world. In spite the growing importance of women entrepreneurs, they are understudied and the scarcity of research on the phenomenon of women's entrepreneurship is also the problems noticed in literature (de Bruin et al., 2006, 2007). A gender gap continues in academic research compared to the significant proportion of business ownership. Palaniappan, Ramgopal and Mani, (2012) further pointed out that poor management; improper planning and allocation of inadequate financial resources are the hurdles of women entrepreneurship success in Somalia. However, women businesses success factor are least discussed in literature with the perspective of Somalia thus the current study is conducted into consideration of following objectives; to identify the impact of government support, fund support, market\& network and socio economic factors on women entrepreneur success in SME in Somalia. Lastly, evaluate the most significant factor influence on success of women entrepreneur among all the selected variables.

\section{Objectives of the Study}

The main objective of the study is to examine factors influencing women entrepreneurs' business success in Somalia.

\subsection{Hypothesis}

H1: There is a significance relationship between government support and success of women entrepreneur.

$\mathrm{H} 2$ : There is a significance relationship between fund support and success of women entrepreneur.

H3: There is a significance relationship between market \& network and success of women entrepreneur.

H4: There is a significance relationship between socio economic and culture factors and success of women entrepreneur.

\section{Literature review}

\subsection{Women Entrepreneurship}

The growing contribution of women as proprietors and owner in commerce has urged the issues related to gender discrimination in entrepreneurship studies. Adnan Alias, (2004) posit that in past years the phenomenon of entrepreneur was associated with masculinity rather than feminine. Hereafter, gender businesses have extensively been used to represents women 
participation in business. Kuratko and Hodgetts (2009) argued that entrepreneur concept is very extensive and wide such as it is known as an innovator or developer who identifies and avails opportunities. And then converts these chances into practicable or marketable ideas that bring values for them as well as for society. They further pointed out that they also have potential to take competitive edge in stiff competition environment and also assume the risk where needed. As Madura (2007) posit that entrepreneurs are the individuals to whom risk at the starting of business is organize and manage.

\subsection{Government Support}

Government support such as providing aids, funds, training projects and tax relaxation can play vital role in the success of women entrepreneur organization. As Nasser, (2012) stated that government supports are beneficial to women entrepreneurs. However, strict policies of the government related to investments and return towards small and medium-sized enterprises adversely influence on women entrepreneur. Likewise, Curran, (2007) Small and medium- sized businesses play an important role to achieve the highest sustainable economic growth and are the key feature of emerging economic development of the country. Further it is argued that the government support to women entrepreneurs in SMEs can play an important role to open the doors of employee opportunities as well as sustainable growth of country economy (Mansor, 2005). Additionally, Świerczek, (2007) argued that the most problematic hurdle in the success of business women in developing countries is insufficient capital includes money, equipment, technology accessibility provided by government in developing countries, education opportunities are very limited for women that are provided by government that is also great hurdle in their success Umoren and Ehigie (2003). The government has to support to attract women in entrepreneurial activities through the provision of capital to start businesses.

\subsection{Market and Network}

Market is an area or a place where forces of demand and supply, operate, and where buyer and sellers interact to each other for pricing information, distributions and channels and also where other networks are developed. Mohammed, (2013) argued that network is one of most important factor for the entrepreneurs to promote their products and services as well to build relations with suppliers and buyers. Jennifer, Lian and Wei, (2012) claimed that the market potential and the current market demand is a major factor that contributes in starting business by women. In addition, Katrina and Anna, (2005) found that women will be more encouraged to start a business if they have a advance network, because these networks allows them to reach the immense population of country as well as world to promote and sale their products and services. Similarly, Wong, (2007) found that for the success of business projects it is necessary for owner to access the most technical and developed network of communication.

\subsection{Socio-Economic and Culture}

Socio-economic and culture have been described as encouraging business activities and it is a base in the sociology of the network accessibility to entrepreneurship (Aldrich and Zimmer, 1986), According to literature review, social economic was described mainly for business activities. However, entrepreneurship is an integral section of social, political, and cultural context so the importance of socio economic culture cannot be ignore. In order to start new business, social network should be activated that would be related to the work and the natural activity (Dubini \& Eldaric, 1991). Kamal, and Rana (2009) mentioned that the business women are motivated by the supports of socio-economic and cultural while economic constraints such as cultural barrier, lack of provision and lack of work skills negatively affect the activities of business women. Moreover, Ekpe and Norsiah (2011) posit that cultural and 


\section{Macrothink

its social economic have impact on women entrepreneurs. These results are similar to the research done by Shastry and Sinha (2010) on social, cultural and economic factors on entrepreneurial development in India, and they found these three factors did influence women's business success. Furthermore, Namdari et al. (2012) study shows that research addresses social, economic and cultural factors such as economic situation, external pressure, family and friend's position, etc., and may affect women in making business decisions.

\subsection{Fund Support}

Indeed, fund is more important factor for doing any business especially for new business development. Towhidur et al. (2013) in Bangladesh found that only the fund support is from is positively impact on women entrepreneurs in SME businesses. Previous studies exposed that less capital leads women entrepreneurs firms towards long-term negative impacts on the performance of the business (Carter \& Allen, 1997). According to Namusonge (2006) the support of leading agencies such as banking institutions and the performance of the business are positively contributed in women entrepreneurs. Further, it is argued that women entrepreneurs faced gender discrimination to avail this support (Mutuku, 2006). In terms of relationships, Gatewood et al. (2004) mentioned that there is a significance relationship between fund support and business success.

\section{Research Methodology}

This research carried out to taken into consideration the various elements that contribute the success factors of women entrepreneur in Somalia. The framework in this study is based on the relationship between governmental support, network, fund support and socio economic and culture as the independent variables while the success factors of women's entrepreneur in Somalia to be the dependent variable. An overview of the research framework is represented in the diagram below:

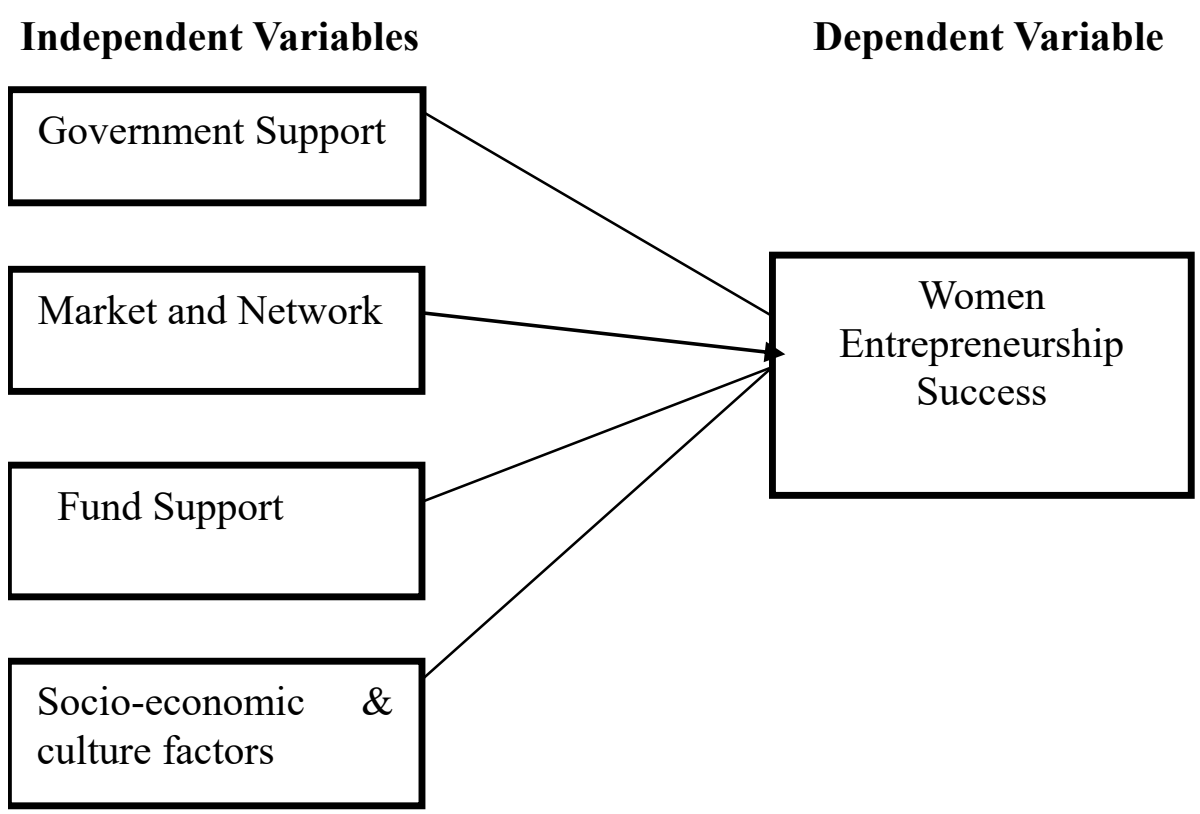

Figure 1. Research Framework 
Women entrepreneur of SMEs in North East Somalia was taken as population of this research. However, total sample of 100 respondents for data collection were chosen from Galkaio, Bossaso and Garoe areas of Somalia. Additionally, researcher used the convenience sampling technique in order to collect the data by distributing the questionnaire randomly to the owners of the businesses. Convenient sampling which is basically non probability in nature however may not be able to get effective responses of the variables in the population but found to be the best option for this study as it is time consuming to get the desired respondents.

\subsection{Data Collection Method and Instrumentation}

Quantitative data was the basic focus of this study. As there were many studies done on entrepreneurship, it is more effectual to acquire better results by using new or primary data by means of questionnaire. Thus, questionnaire was selected as instrumentation to collect data from target sample. Researcher randomly distributed questionnaire to 100 women entrepreneurs in selected areas. Moreover, pick and drop method was used to collect data through questionnaire. There were 2 sections in a questionnaire in which section A was designed to get information on the profiles of the respondents. Section B was made up of several questions related to variables and all these questions were designed to using five-point Likert scale.

\section{Findings and Analysis}

\subsection{Descriptive Analysis}

\subsubsection{Demographic Information}

Above table reveals that married women were dominant at $56 \%$ and the rest of them were single entrepreneur 44\%. In context of age 30-39 (Frequency; 37, percentage; 37\%) years old women entrepreneurs were in majority and age below 20 years (Frequency; 10, percentage; $10 \%$ ) were least participant in this survey. In terms of level of education, the results demonstrates that most of entrepreneur respondents got college education (Frequency; 35, percentage; 35\%) and PHD (Frequency; 12, percentage; 12\%) participant were least in number.

In case of business ages 1-5 years (Frequency; 39, percentage; 39.0\%) were leading while Age group 16-20 years (Frequency; 8, percentage; 8\%) were less participate. In business type mostly women owned clothing and fashion business (Frequency; 35, percentage; 35\%) while very few businesses found related to production of furniture (Frequency; 4, percentage; 4\%). Furthermore, in case of employees strength in women owned business, mostly SMEs consists of less than 5 employees (Frequency; 40, percentage; 40\%) while very few organizations having 50- 140 employees (Frequency; 21, percentage; 21\%). Moreover, mostly women started their business by individual saving (Frequency; 61, percentage; 61\%) while very limited women were supported by family (Frequency; 13, percentage; 13\%) and government (Frequency; 10, percentage; 10\%), further, mostly women owned their store (Frequency; 66, percentage; 66\%) and very few entrepreneur doing online business (Frequency; 10, percentage; $10 \%)$. 
Table 1. Frequency of Respondent Profile

\begin{tabular}{|c|c|c|c|}
\hline & Classification & Frequency & percentage \\
\hline \multirow{2}{*}{ Marital Status } & Single & 44 & 44.0 \\
\hline & Married & 56 & 56.0 \\
\hline \multirow{6}{*}{ Age } & Below 20 & 10 & 10.0 \\
\hline & $20-29$ & 17 & 17.0 \\
\hline & $30-39$ & 37 & 37.0 \\
\hline & $40-49$ & 23 & 23.0 \\
\hline & $50-50$ & 11 & 11.0 \\
\hline & 60 Plus & 2 & 2.0 \\
\hline \multirow{4}{*}{ Education } & PHD & 12 & 12.0 \\
\hline & Masters & 26 & 26.0 \\
\hline & College & 35 & 35.0 \\
\hline & High School & 27 & 27.0 \\
\hline Business Age & $\begin{array}{l}1-5 \text { years } \\
6-10 \text { years } \\
11-15 \text { years } \\
16-20 \text { years } \\
21 \text { years and above } \\
\end{array}$ & $\begin{array}{l}39 \\
19 \\
18 \\
8 \\
16\end{array}$ & $\begin{array}{l}39.0 \\
19.0 \\
18.0 \\
8.0 \\
16.0 \\
\end{array}$ \\
\hline \multirow[t]{7}{*}{ Business type } & Food \& Beverage & 14 & 14.0 \\
\hline & Beauty / Cosmetic & 23 & 23.0 \\
\hline & Clothing / Fashion & 35 & 35.0 \\
\hline & Agriculture & 6 & 6.0 \\
\hline & Production furniture & 4 & 4.0 \\
\hline & Services & 10 & 10.0 \\
\hline & Others & 8 & 8.0 \\
\hline \multirow[t]{3}{*}{ Number of employee } & less than 5 & 40 & 40.0 \\
\hline & $4-49$ & 39 & 39.0 \\
\hline & $50-140$ & 21 & 21.0 \\
\hline \multirow[t]{3}{*}{ Way of doing business } & Online & 10 & 10.0 \\
\hline & Store & 66 & 66.0 \\
\hline & Others & 24 & 24.0 \\
\hline \multirow[t]{5}{*}{ Source of capital } & Family & 13 & 13.0 \\
\hline & Individual or Joint Savings & 61 & 61.0 \\
\hline & Government program & 10 & 10.0 \\
\hline & Bank Loan & 11 & 11.0 \\
\hline & Others & 5 & 5.0 \\
\hline \multirow[t]{4}{*}{ Experience before start business } & Unemployed & 32 & 32.0 \\
\hline & Self- Employed & 38 & 38.0 \\
\hline & Office Worker & 27 & 27.0 \\
\hline & Others & 3 & 3.0 \\
\hline
\end{tabular}

\subsection{Descriptive Analysis for Mean}

This part of analysis is carried out to check the agreement level of customers about each variable. Mean value less than 3 shows low influence, less than 4 shows moderate impact and the value 4 or greater than 4 shows high impact. 
Table 2. Mean Analysis

\begin{tabular}{|l|c|c|}
\hline Variables & Mean & Std. Deviation \\
\hline Women Entrepreneur Success & 4.06 & .405 \\
\hline Government Support & 3.90 & .466 \\
\hline Fund support & 3.72 & .546 \\
\hline Market \& Networking & 3.36 & .586 \\
\hline Socio economic \& culture factors & 3.98 & .401 \\
\hline
\end{tabular}

Above table pointed out that the mean value range of all variables is between 3.36 to 4.06 with standard deviation from .401 to .586 which indicates that mostly respondents in this study responded within the scale of agree to strongly agree thus the most of the items measuring the success of government support, fund support, market\& networking and socio economic and culture variables.

However to measure the uncertainty, standard deviation is used. High standard deviation show more variation in the data and indicates that values are so far from actual values. Thus in this research S.D values are very low which indicates that values are near to actual values and the responses of respondents are not very similar with each other.

\subsection{Reliability Analysis}

For the adequacy and accuracy of data collection instrument reliability analysis is very crucial. Indeed for data analysis, to give the evidences of data cannot be neglected. Therefore, it is important to check the reliability before further analysis. Cronbach's Alpha value should be equal or greater than .70 for reliable data (Kumar, 2014; Hair et al., 2010).

Table 3. Reliability Analysis

\begin{tabular}{|l|l|}
\hline Variables & Cronbach's Alpha Value \\
\hline Women Entrepreneur Success & 0.760 \\
\hline Government Support & 0.752 \\
\hline Fund support & 0.740 \\
\hline Market \& Networking & 0.722 \\
\hline Socio economic and culture factors & 0.745 \\
\hline
\end{tabular}

It is demonstrated in table 2 that the Cronbach's alpha value for all variables such as success factors (.760), government support (.752), fund support (.740), market \& networking (0.722) and socio economic and culture factors (.745) is greater than .70 which indicates that all variables are reliable for the study and instrumentation is best fit to the study and findings are accurate and reliable.

\subsection{Multiple Regression Analysis}

Multivariate analysis is used to check the extent of relationship between two or more variables. Further it shows the impact of independent variables on dependent variable. This test is interpreted according to B value, if it significant at less than .05 level of significant we will accept the hypothesis otherwise hypothesis will reject. In particularly this is a statistical tool that allows examining how multiple independent variables are related to a dependent variable. However model summary, coefficient table and ANOVA table is presented below. 
Table 4. Model Summary

\begin{tabular}{|l|r|r|r|r|}
\hline Model & R & R Square & \multicolumn{1}{|c|}{$\begin{array}{c}\text { Adjusted R } \\
\text { Square }\end{array}$} & $\begin{array}{l}\text { Std. Error of the } \\
\text { Estimate }\end{array}$ \\
\hline 1 & $.712^{\mathrm{a}}$ & .506 & .494 & .4491 \\
\hline
\end{tabular}

a. Predictors: (Constant), Government support, Fund support, Market \& Networking, Socio-economic and culture factor

In table 4 , it is found that the adjusted $\mathrm{R}^{2}$ of the model is .712 with the $\mathrm{R}^{2}=.506$ which indicates that the linear regression explains $50.6 \%$ of the variance in the data. Basically $\mathrm{R}$ square value is the proportion of variance in the dependent variable which explained by independent variables. Therefore the value $\mathrm{R}$ square .766 shows that the independent variables (government support, fund support, market \& networking and socio economic factors) explain variability and predict the women entrepreneur success. However in case of the current model summary results, the value of $\mathrm{R}=.712$ indicates the high level of prediction.

Table 5. Coefficients ${ }^{\mathrm{a}}$

\begin{tabular}{|c|c|c|c|c|c|}
\hline \multirow[t]{2}{*}{ Model } & \multicolumn{2}{|c|}{$\begin{array}{l}\text { Unstandardized } \\
\text { Coefficients }\end{array}$} & $\begin{array}{l}\text { Standardized } \\
\text { Coefficients }\end{array}$ & \multirow[t]{2}{*}{$\mathrm{t}$} & \multirow[t]{2}{*}{ Sig. } \\
\hline & B & Std. Error & Beta & & \\
\hline (Constant) & .443 & .216 & & 2.054 & .042 \\
\hline Government support & .385 & .060 & .345 & 7.258 & .000 \\
\hline Fund support & .181 & .043 & .210 & 4.173 & .000 \\
\hline Market \& networking & .079 & .039 & .088 & 2.054 & .040 \\
\hline $\begin{array}{l}\text { Socio-economic and } \\
\text { culture factors }\end{array}$ & .018 & .041 & .022 & .4365 & .663 \\
\hline
\end{tabular}

Above Unstandardized coefficients indicate how much the women entrepreneur success varies with an independent variable (government support, fund support, market \& networking and socio economic and culture factors) when all other independent variables are held constant. B is significant if $\mathrm{p}<.05$. Therefore, above table 5 shows the results of independent variable impact on dependent variable, $\mathrm{B}$ value of Government support $(\mathrm{B}=.385$; Sig. $=.000)$, fund support $(\mathrm{B}=.181$; Sig. $=.000)$, market \& networking $(\mathrm{B}=.079$; Sig. $=.040) \quad$ shows the impact of these variables on women entrepreneur success in Somalia. Government support is more crucial factor which largely impact on business women success in Somalia. Socio economic result indicates that there is no relationship between socio economic factor and women entrepreneur success in Somalia.

\section{Discussion and Conclusion}

The main purpose of this research is to found whether there is any relationship or impact of government support, fund support, market \& networking and socio economic and culture factors on women entrepreneur success in SMEs in Somalia. However, results of the analysis 
revealed that all the variables except socio economic factor to justifiable play its role in success of business women. The evidence exposed from the bivariate analysis specified that the most the impact of market\& networking and fund support is not very high. Hence, it may be very beneficial to focus in-depth about numerous other components or items which may highly influenced on the success of entrepreneurship among women and can push them to the next higher level. Besides, the importance of government support had been additional established based on the findings in which the beta value of 0.385 highly recommends its usefulness in shaping the success factors of the women businesses. Indeed market \& networking and fund support also meaningfully played its practicality.

Nonetheless, past studies suggested the importance of fund support in supporting someone to endeavor into entrepreneurship, but its involvement in this study could be consider mix as revealed by the significant value of .000 . Therefore, the total findings based on the relationship of three dimensions (government support, fund support and market \& networking) capable to produce an adequate model for making women as successful entrepreneurs. Thus, the overall conclusion shows that government support, fund support and market \& networking are important characteristics to promote successful environmental, family and personal attributes is important in order to promote successful business projects among women entrepreneur in Somalia. For further studies, more other variables such as human resource practices, family support, personal attributes and use of technology can be explored for supporting women toward successful entrepreneurship.

\section{References}

Abdirahman, M. (2016). Challenges and Motivation of women entrepreneurs in Somali region of Ethiopia. Sosyoloji Konferanslar1, No: 54 (2016-2)/169-198.

Adnan, A. (2004). Entrepreneur and Entrepreneurship, Fundamentals of Entrepreneurship. U.E.S. Group. Selangor, Pearson, Prentice Hall.

Aldrich, H., \& Zimmer, C. (1986). Entrepreneurship through social networks. In D. L. (Ed.), The art and science of entrepreneurship (pp. 3-23). Cambridge, MA: Ballinger.

Ali, H. A., \& Ali, S. Y. A., (2013). Challenges and Constraints Faced by Somali Women Entrepreneurs in Benadir Region. Interdisciplinary Journal of Contemporary Research in Business, 5(2).

Ali, Y. (2012). Changing role of women in Somalia; an empirical survey of social and economic contribution of Somali women entrepreneurs in Banaadir region. Academic Research International, 3(1).

Alina, G. M. (2007). The entrepreneur's motivation, human and financial capital as determining factors of growth for new companies. The Colombian case.

Benzing, C., Chu, H. M., \& Kara, O. (2009). Entrepreneurs in Turkey: A Factor Analysis of Motivations, Success Factors and Problems. Journal of Small Business Management, 58-91.

Britteny, H. (2014). Small Business Success Tips for Women Entrepreneurs. Retrieved from http://www.businessnewsdaily.com/7444-5-Small-business-Success,tips-for-women entrepreneurs.

Chan, J. K. L., \& Quah, W. B. (2012). Start-up factors for small and medium-sized accommodation businesses in Sabah, Malaysia: Push and pull factors. Asia Pacific Journal of Tourism Research, 17(1), 49-62. 
Chitra, M., Priya, A. R. S., Kalpana, B., \& Raj, K. (2014). Influence of Personal Factor on women entrepreneurs for success in Beauty salon industry. International Journal of Information Technology \& Computer Science, 15(1), 2091-1610.

Chuthamas, C., Aminul, I., \& Dayang, H. M. (2011). Factors Affecting Business Success of Small \& Medium Enterprises (SMEs) in Thailand. Retrieved from https://www.researchgate.net/publication/228461885.

Clare, B. (2005). Barriers to women achieving their entrepreneurial potential; Women risk International Journal of Entrepreneurial Behavior \& Research, 11, 144-161.

De Bruin, A., Brush, C., \& Welter, F. (2006). Introduction to the special issue: towards building cumulative knowledge on women's entrepreneurship. Entrepreneurship Theory \& Practice, 30(5), 585-94.

De Bruin, A., Brush, C., \& Welter, F. (2007). Advancing a framework for coherent research on women's entrepreneurship. Entrepreneurship Theory \& Practice, 31(3), 323-39.

Dubini, P., \& Aldrich, H. (1991). Personal and Extended Networks are Central to the Entrepreneurial Process. Journal of Business Venturing, 6(5), 305-313.

Ducker, P. F. (1985). Innovation and Entrepreneurship. New York: Harper Business.

Ekpe, I., Norsiah, M., \& Razli, C. R. (2011). Attributes, Environment Factors and Women Entrepreneurial Activity: AN L literature Review. Asian Social-Science, 7(9).

Eshetu, B., \& Zeleke, W. (2008).Women entrepreneurship in micro, small and medium enterprises: The case of Ethiopia. Journal of international women's studies, 10(2). Retrieved from www.bds-ethiopia.net

Gatewood, E. J., Brush, C. G., Carter, N. M., Greene, P. G., \& Hart, M. M. (2004).Women entrepreneurs, growth, and implications for the Classroom. Coleman Foundation White Paper Series for the United. States Association for Small Business and Entrepreneurship.

Haifa, F. (2012). Women Entrepreneurs in Saudi Arabia: Investigating Strategies used by Successful Saudi Women Entrepreneurs, master's thesis. Lincoln University, New Zealand.

Hair, J., Black, W., Babin, B., \& Anderson, R. (2010). Multivariate data analysis: a global perspective (7th ed.). Upper Saddle River, NJ: Pearson.

Hisrich, R. D., \& Brush, C. G. (1986). The woman entrepreneurs: Starting, financing and managing a successful new business. Lexington, MA: Lexington Books.

ILO. (2008). Women Entrepreneurs in Kenya, factors affecting Women Entrepreneurs in Micro and Small Enterprises in Kenya. Geneva. International labor organization.

ILO. (2014). Institutional and policy Assessment of factors affecting women entrepreneurs in micro and small entrepreneurs in Hargeisa and Mogadishu, Somalia. Geneva, International Labor Organization.

Ingait, P. C. (2015). The Socio-economic factors affecting small business. Retrieved from $\mathrm{http}: / /$ smallbusiness.chron.com/socioeconomic-factors-affecting-Small-businesses-7323 4.html

Isidore, E. (2015). Women Entrepreneurs and Economic Development in Nigeria: Characteristics for Success. International Journal of Business and Social Science, 2(1). Retrieved from https://www.researchgate.net/publication/268177390 
Kamal, N., \& Wojoud, R. M., \& Rana, N. (2009). Factors that affect women Entrepreneurs evidence from an emerging economy. International Journal of Organizational Analysis, 17(3), 225-247.

Kartini. M. R., \& Haslina. C. Z. M., \& Norudin. M. (2015). Success Factors among Women Entrepreneurs in Malaysia. International academic research journal of business and technology, 1(2).

Kinyau, M. (2015). Entrepreurial Factors Influencing the Performance of Youth Enterprise Development Funded Youth Owned Enterprises In Kirinyaga Country Strategic. Journal of Business \& Change Management, 2(2). Retrieved http:/www.strategicjournals.com/ index.php/journal/article/view/183/0.

Kumar, D. (2014). Socio- cultural Influence on Women Entrepreneurs: A Study of Uttara khand Stat., International Journal of Trade and Commerce-IIARTC, 3(1).

Kumar, G. R. (2014). Purchase decision of Indian consumers: the factors of attraction while purchasing car. Studies in Business and Economics, 9(3), 29-42.

Kuratko, D. F., \& Hodgetts, R. M. (2009). Entrepreneurship-Theory, Process, Practice (2nd Ed.). South-Western Cengage Learning, USA.

Madura, J. (2007). Introduction to Business (4th ed.). South Western Educational Publishing.

Meyer, N. (2009). An investigation into the Determinants of women entrepreneurship. Potchefstroom: North- West University.

Mitra, R. (2002). The Growth Pattern of Women-Run Enterprises: An Empirical Study in India. Journal of Developmental Entrepreneurship, 7(2), 217-237.

Mohammed, I. A. (2013). Economic Analysis of the Structure Integration and Performance of Rice Markets in Dekina Local Government Area of Kogi State- Nigeria, Journal of Agriculture, Forestry and the Social Sciences (JOAFSS), 11(1).

Muhammad, S. B. (2012). Determinants of Business Success Trust or Business Policy. Journal of Arts, Science \& Commerce.

Mulu B. H., (2015). Micro and Small Scale Enterprises (MSEs) Development Services in women's Entrepreneurial Start-Ups in Ethiopia. Journal of Behavioral Economics, Finance, Entrepreneurship, Accounting and Transport, 2(4), 77-88. https://doi.org/10.12691/jbe-2-4-1

Mutuku, M. (2006). Entrepreneurial Learning among Women Micro-Entrepreneurs in Kenyan Dairy Processing Industry. A paper presented at the 3rd International Entrepreneurship Conference, Nairobi.

Namdari, R., Raz, S., \& Aramoon, H. (2012). A Survey on Socio- Cultural and Environment Factors Affecting Women Entrepreneurs in Khouzestan Province, Australian Journal of Basic and Applied Sciences, 6(13), 11-17.

Namusonge, G. S. (2006). Entrepreneurial Finance and Micro, Small and Medium Enterprises (MSME) Innovation in Kenya. Technological and Industrialization Conference, JKUAT Nairobi.

Naser, K. W., \& Nuseibeh, R. (2009). Factors that affect women entrepreneurs: Evidence from an emerging economy. International Journal of Organizational Analysis, 17(3), 225-247.

Norudin, M. (2005) Woman in Business: Determinants for Venturing in Malaysian SMEs. 
Studia Universitas Babes- Bolyai, Negotia, No.2.

Oluwole, I., \& Dominic, A. (2014). Women entrepreneurs as small- medium Enterprise operations and their roles socio-economic development in OTA, Nigeria. International Journal of Economics, Business and Finance, 2(1), 1-10. Retrieved from http://ijebf.com

Palaniappan, G., Ramanigopal, C. S., \& Mani, A. (2012). A study on problems and prospects of Women Entrepreneurs with special reference to ERODE DISTRICT. Journal of Physical and Social Sciences, 2(3).

Rashid, K. M., Ngah, H. C., Mohamed, Z., \& Mansor, N. (2015). Success factors among women entrepreneur in Malaysia. International Academic Research Journal of Business and Technology, 1(2), 28-36.

Salleh, Z., \& Osman, M .H. M., (2007). Goal Orientation and Typology of women entrepreneurs. Journal kemanusiaan bil.

Stefanovic, I., Prokic, S., \& Rankovič, L. (2010). Motivational and success factors of entrepreneurs: the evidence from a developing country.

Swierczek, F. W., \& Ha, T. T. (2007). Entrepreneurial orientation uncertainty avoidance and firm performance: an analysis of Thai and Vietnamese SMEs. International Journal of Entrepreneurship and Innovation, 4(1), 46-58.

Towhidur, R. (2013). Factors Considered Important for Establishing Small and Medium Enterprises by Women Entrepreneurs. A Study on Khulna City. Journal Business and Management Horizons, 1(1), 24-29.

Umoren, E. U., \& Ehigie, O. B. B. (2003). Psychological Factors Influencing Perceived Entrepreneurial Success among Nigerian Women in Small-Scale Businesses. Journal of International Women's Studies, 5(1), 78-95.

Vichayanan, R., \& Muhammad. M. (2016). Factors affecting entrepreneurial management in Bangladesh: an empirical analysis. Problems and Perspectives in Management, 14(3-3). http://10.21511/ppm.14(3-3).2016.11

Zhang, J., \& Wong, P. (2008). Networks vs. market methods in high-tech venture fundraising: the impact of institutional environment. Entrepreneurship \& Regional Development: An International Journal, 20(5), 409-430.

\section{Copyright Disclaimer}

Copyright reserved by the author(s).

This article is an open-access article distributed under the terms and conditions of the Creative Commons Attribution license (http://creativecommons.org/licenses/by/3.0/). 